\title{
Effective Predictive Parenting for Positive Academic Performance in Children: Implications for Professional Counselling
}

\author{
Nwaoba Christiana Ngozi \\ Department of Agricultural and Home Economics Education \\ Michael Okpara University of Agriculture, Umudike, Abia State, Nigeria
}

\section{Doi:10.5901/jesr.2013.v3n8p75}

\begin{abstract}
The quality of training a parent gives to his child at home goes a long way in determining his academic performance at school. Predictive parenting promotes intellectual curiosity, motivation and the desire to achieve academic excellence. This paper highlights the concepts of parenting, predictive parenting and academic performance of children, tips on effective predictive parenting such as setting objectives for the family, instituting effective parent-child communication and building harmony in the home. It equally highlights the role of professional counselling in helping parents adopt predictive parenting in families through the use of proactive counselling strategies such as school-Based family counselling, behaviour modification, parents fora and others. The paper recommends among other things that efforts should be intensified by governmental and non-governmental organizations to give adequate information to parents on predictive parenting that leads to positive academic performance in children.
\end{abstract}

Keywords: parenting, predictive parenting, academic performance and counselling.

\section{Introduction}

Children are gifts from God to human parents-gifts with the responsibility to keep and position well for useful existence. These days, useful existence for children includes providing them good conditions for positive academic performance at school. It also involves removing those hindrances to academic excellence. This means brining up children so that they do not grow up to become unruly, notorious nuisance and or constant sources of sorrow and shame to both parents and the society. And bringing up a child in this positive manner depends largely on the type of parenting technique that exists in the child's family.

The parenting technique used in child rearing accounts for not only the differences in personality and needs in children but also differences in academic performance (Imona, 2006). Okeke (2001) opined that it also influences children's career choice, social interaction, life decisions, academic expectations as well as going a long way to determining how the development of our country could be measured. Hence the need for parents to jettison exploitative parenting styles that hinder academic progress in children and adopt better parenting technique such as predictive parenting. And for proper adoption of predictive parenting, professional family counselling cannot remain complacent.

\section{Concept of Parenting}

Parenting is a promise to devote time, resources and best efforts to the emotional, physical, intellectual and social development of a child. Parenting is also considered as bringing up a child in orderly manner so that the child on getting to school will see school activities as complimenting what is learnt at home and so is better able to achieve positive transfer of knowledge and skills 
from home to school to enhance his academic performance. NTI (2009) noted that positive transfer that facilities academic success is possible when knowledge and skills acquired in one learning environment (home being the first learning environment for a child) is similar to the ones in another environment such as school environment. This is the reason for Okon (2009) to assert that the home determines a child's level of academic performance in school.

Parenting is the art of carrying out the responsibility to keep and position children for useful living. It is an art of raising up a young person, hence psychologists (Baumrind (1992), Cowen (2003) and Coleridge (2009) related that parenting is a process of raising and nurturing a child. They explained further that parenting also involves the process of caring for your child's academic performance.

Parenting is the process of bringing up a child in a manner that he will not be deprived of his education and other basic rights no matter the level of economic depression in the country. It involves nurturing that does not over labour the child so that he would be strong and able to cope with his academic activities. Imon (2006) reported that children who are over laboured are most times found sleeping in classes because of tiredness, which is a hindrance to positive academic performance in children.

Prominent among the factors that influence parenting generally are: relationship, communication between co-parents and the academic values that are upheld and promoted by both father and mother in a home. This is similar to good communication between parents and their children in facilitating consistency parenting and the values that are promoted by both parents, which provide clear guidance and expectation for the child's academic performance and other forms of his behaviour, (weiss and scotwarz, 1996). All these indicate that parenting involves many responsibilities such as setting rules and regulations as a guild for the children to follow, providing educational resources that ensure consistency in school attendance, motivating, encouraging them especially when their spirit is low, forming friendship with them among others.

\section{Predictive Parenting and Academic Performance}

Predictive parenting is a conscious purposeful effort to influence the attitudes, beliefs and performances of our children. Nwazor, (2006) related that predictive parenting refers to setting up the best and most positive condition for the child's positive academic performances in the course of bringing up the child. She also explained that predictive parenting prevents academic failure.

In predictive parenting, parents look for opportunities to build their child's subconscious mind. Thus in predictive parenting parents aim at the following:

- Giving the child a more positive direction. This is achieved through performing all that predictive parenting requires such as quality time and personal sacrifice for the child's academic success and his general welfare. Predictive parents pray for their children's success at school, discuss with their children concerning their academic experiences on daily basis, check and assist them in completing school assignments, care, play with them at their leisure moments, monitor and mentor them.

- Creating more self confidence or self esteem in children: In predictive parenting, parents show their children unreserved love and focus on the good aspect of their children's life. This serves as a source of encouragement to them. Parents have a question and answer rapport with their children consistently, sharing their own experiences especially as it concerns academics with their children.

Predictive parents do not allow their children to labour for their up keep at school. And even when their child is serving as a babysitter to a close relative, Predictive parents monitor school task given to their children as well as the general education provided to their children. According to Nwazor (2006), in predictive parenting, parents avoid nagging and undue criticisms even when the child has not done it well or he has missed the goal he aimed at. Their criticisms are always 
constructive. Feedback is given out of love. It is very tempting for most parents to criticize everything a child does and keep on describing him negatively (e.g. giving the child derogatory names that depict failure). This makes the child to loose self confidence. In predictive parenting, parents appreciate the good parts and praise their child so that he does not get frustrated even when he has performed unevenly in his academics (capability in one area and extremely weak in others). On noticing such an uneven performance in school work, the predictive parent does everything he can to create more self confidence and high self esteem in the child by making the child to still place high value on himself that will ensure huge success next time around. This is why when Olayinka (1998) related that good parents cannot afford to remain dormant while the constraints in the academic performance of their children persist, he was referring to predictive parents.

Other things predictive parenting aims at for positive academic performance in children are:

Giving the child proper understanding of the rules of personal responsibility. This means that children should be taught by parents to take direct responsibility for their actions. The principle of personal responsibility states that each individual is responsible for his own actions. When a child knows this right from home he will be more careful' about what actions to take to enhance his academic performance and boost his self-esteem. This in turn develops in children attitudes and habits that lead to self- sufficiency and success in all life endeavors including schooling Wilkerson, (2007), Okonkwo, (2009) opined that it helps in preventing academic failure as well as in promoting positive academic performance in children.

Academic failure is a process whereby a child (e.g. a student) slips farther and farther behind his peers and gradually disconnects from educational system. Academic problems are many and diverse. If ignored and unresolved such problems and dilemma are capable of distorting and thwarting the capabilities and potentialities of the student involved. It helps children in making decisions against involvement in various dimensions of examination malpractices. Nwankwo, (2005), believes that the quality of academic performance among children these days that is nothing to write home about stem from poor parenting techniques that exist in families. The consequences of children's massive academic failure and its end product are grave and far reaching towards the development of our country, yet, predictive parenting/technique that addresses them is underutilized due to ignorance (Nwazor, 2006).

\section{Tips for Effective Predictive Parenting}

Tips for effective predictive parenting as identified by (Nwazor, 2003) include:

- Setting objective for the home.

- Effective parent-child communication and

- Building harmony in the home.

\section{Examples of the Objectives Predictive Parents must Set in Homes Include:}

- A home where children will want to spend enough time for vigorous scholastics activities such as studying their books without having to be persuaded to do so.

- A peaceful mutual supportive environment in the home where children are guided for the right choice of school subjects.

- A home where the children develop spirit of co-operation and mutual understanding that find it fulfillment in shunning elements of involvement in examination malpractices at school.

- A home where the children are helped to form good study habit.

- A home where the children learn to develop a strong sense of likeness for school subjects and school teachers.

- A home where children are aided to develop strong hatred for absenteeism, truancy, 
laziness to school.

- A home where children learn to develop a strong sense of self confidence. A child that has high self confidence does not resort to outside help in examination in order to appear an academic "success" (Nwideh, 1999).

- A home where children learn to be honest and assertive rather than being conforming children. Children who learn right from home to be honest and assertive, hardly conform with the bad eggs in the class (Ngelelota, 1998)

- A home where children acquire skills for good academic success.

- A home where children learn to develop a strong sense of personal responsibility and accomplishment. In other words, predictive parents set up a home where children are motivated for greater performances.

This aspect of predictive parenting have influenced many scholars such as Morrisen and Melyntyre (1993), Nwazor (2006) Wilkerson (2007), Cool (2008) who supported that in teaching and training our children in the homes, that parents must have objectives and goals; they should be realistic and systematic and that the children should be taught everything about life including the essence of going to school, the need for high academic performance at school and the avoidance of those attitudes that hinder positive academic performance, such as laziness, loitering, truancy among others.

Koo (2008) opined that every parent should adopt predictive parenting that aims at training children to have the courage to say "No" even when all around them are going the popular but wrong way, such as conforming to carry out examination malpractices. Sears, Maccoby and Levin (2003) confirmed this by observing that child-rearing practices involving predictive parenting affect the academic performance of individuals in schools. Morrison and Mclyntyre (1993) asserted that success at school work involves the innovation which allows one to capitalize upon one's education, especially where there is no gap in communication between parents and their children.

\section{Effective Parent-Child Communication}

This simply refers to the exchange of thoughts and ideas between parents and their children that could make the understanding of school work possible. Nwazor (2003) insists that to ensure effective predictive parenting, parents should develop the habit of conversing and listening to their children - ask questions that will draw them out for discussions that are dominated by school tasks. It is through this way that parents get to know the challenges to their children's academic performances and make serious efforts to help them face the challenges squarely. Horward (2006) related that in predictive parenting, children are helped to develop the fortitude to face learning problems and tackle them squarely. Therefore for effective predictive parenting, parents should be open to their children so that the children can discuss their academic problems with them as if they trust them as their friends (Imon and Asita, 2012).

There are tools for effective parent-child communication. Nwazor (2006) introduced a single mnemonics that predictive parents can use(as tools) to remind themselves about issues that enhance parent-child communication for positive academic performance of their children as "T-A-L$\mathrm{K}^{\prime \prime}$. viz .T stands for Time for the child. This means that parents need to make out time regularly to interact with their children especially as it concerns their academics. "A" stands for Assurance. This means that children need to be assured of their parent's presence and availability. This is why predictive parents often visit schools of their children to ascertain how far they are coping with the academic challenges and what they can do to facilitate the children's learning in the schools. "L" stands for Listen. This means that parents need to attentively listen to what their children have to say. Children generally want to be assured of their parent's availability to listen to what they want to talk about. And so parents need not dismiss the concerns of children with a wave of the hand. "K" stands for Keen interest. Parents need to show keen interest in what children want to say. This usually encourages children to talk more freely with parents concerning hindrances to positive 
academic performance such as lack of text books, writing materials, late payment of fees and others. This is why in predictive parenting; there are tools for living that focus attention to academic activities. For positive performance in children parents could readily pick one at a time and discuss with their children. Examples include: school work; the role of parents in the academic performances of children; the reason for going to school among others.

\section{Building Harmony in the Home:}

Harmony means peace. It is a kind of peaceful existence (agreement) that motivates members of a family especially children to positive academic achievement while home is the house or flat or apartment that one lives with one's family (Hornby, 2000). The home environment sets the tone of what impression the children acquire about academics as they are being reared. Harmony in the home enhances the confidence of children in their parents that facilitates their performances at school. It also helps children to frequently contribute to the peace in the home through high academic performance Nwaoba, (2011), Koo's, (2008)finding showed that at different times, parents have all missed the mark and have aided to the disharmony in the homes that hinder their children's positive academic performances .

In stressing the need for creating harmony in the home for children's positive academic performance (Nwazor, 2006) outlined some of the major ways of building harmony in homes, viz:

$>$ Keeping your voice down even when you are giving a major correction in your child academic work.

$>$ Giving each child a turn to talk about his experiences at school at meal time.

> Always treat every child with equal respect. Do not look down on any child even those who are performing academically below expectations.

$>$ Set rules in the home concerning academic achievement and stick to them and others.

\section{Theoretical Framework}

This paper is based on the Gestalt theory because its view and methods of application seem most appropriate to the writer's aim and purpose. The Gestalt theory is an essential form of psychotherapy that emphasizes personal responsibility, individuals' experiences in the present moment and self regulating adjustments people should make as a result of their overall situations. The theory itself emphasizes self acceptance, change and actions rather than talks which are very essential ingredients in performing successfully in academic life. This theory is very relevant to the paper because the objectives are to enable individuals such as parents to become more fully aware of and creatively alive to the type of parenting (technique) that facilitate positive academic performance in their children. A child that performs poorly in academics can be made to be aware of his poor academic status and the need to shift from poor to good and be free from failures without losing his self value.

\section{Academic Performance and Parenting}

Positive academic performance is perceived as the child's ability and efforts to score high in school courses of instruction. Many Nigerians are worried today because of recent mass failure in examinations which is traced to poor child rearing techniques in the homes. Hence William (2000) posited that child rearing practices seriously determine the academic performances of individuals in the school and so defined academic success in terms of the acquisition of different types of knowledge and cognitive skills. Popo (1998) defined academic performance as the duty of an individual to attend school according to set standards or rules guiding school or class attendance. A child who is inconsistent in school attendance, often late to school, plays truancy and sleeps in class due to over labour can at best perform below average academically no matter how intelligent 
he is naturally. The same thing applies to a school child who is educationally neglected by his parents or guardian.

\section{Implication for Professional Counselling}

Counselling is a helping relationship between the counsellor and the counsellee It aims at helping learners adjust properly to school programme by helping them to solve problems that hinder their academic performance; be it problem from home or school. Thus, professional counselling services can not be over looked if school children are to perform excellently in their academics. This informs Adewuyi's (2009) assertion that professional counselling involves consultation, discussion, deliberation, exchange of ideals and helping to change situations that are maintaining people's problems through the inculcation of self understanding in the people concerned. Part of the duty of a professional counsellor in the school system to effectively enhance excellent performance in learners include helping parents of the school children to understand how exploitative most of the parenting techniques that exist in their various homes are, (Nwazor, 2006), the need to adopt predictive parenting (technique) and what predictive parenting involves in order to facilitate excellent academic performance in children.

The quest for academic excellent is in the Nigeria National Policy on Education (2004:51)which states that Educational services facilitate the implication of educational policy, the attainment of policy goals and the promotion of effectiveness of educational system" This is in line with Anagbogu (2004), Onwuasanya and Okeke,(2008) when they in their various studies, related that the role of professional counselling in a school whose students perform poorly cannot be over emphasized; in that when an effective professional counsellor is able to counsel with the parents of the students and uses his expertise to treat the students whose behavioural problems emanate from the home, using appropriate behaviour modification techniques both the students' academic performance and the tone of the school will definitely change for better. Anagbogu (2004) enumerated such problems as poor school attendance, lack of concentration, negative self-concept, lesson in-attentiveness, uneven performance among others. Moreover, Castaldi (2007) noted that lack of school based-family counselling is manifested when pupil's academic performance is poor due to lapses on the part of parents and guardians. All these imply the use of proactive counselling techniques such as school-based-family counselling and behaviour modification programmes, parent fora and others in helping parents to adopt predictive parenting in their homes, facilitated through the sstrategy of home-visits.

School based-family counselling is a kind of treatment technique based on advice and information given by a professional counsellor who is an expert in family issues. The professional counsellor does this by integrating school counselling models to solve problems that affect a child's academic performance in order to reinforce positive change in the child. Home-visit in which the counsellor enters into counselling relationship with the parents in their residence or office to exchange ideas on how best to aid a child in his academics is part of it. It enables parents take active part in whatever wise decisions and choices their children are helped to make with the school counsellor towards ensuring positive academic performance, such as decisions against lateness to school, truancy, non-payment or late payment of school fees, lack of concentration and others (nwaoba, 2011). A child who is physically abused by his parents or guardian through overlabour, child leasing, child abduction among others that hinder his positive academic performance could be helped using these methods.

Organizing parents Fora during Parents-Teachers Association Meetings (PTA) and open days in school could constitute teachable moments for a professional counsellor to help parents develop the needed interest to adopt predictive parenting. Family life education is part and parcel of the School based-family counselling. In this, a professional counsellor uses his expert knowledge to drill parents on the programme of predictive parenting/technique accompanied with a clarion call for its adoption in families by oral presentations, video clips of predictive parents and their children or 
talks by invited resource persons.

Moreso, while the professional counsellor is using his expertise to help parents adopt predictive parenting he is also working on the school children for positive behavioural change to ensure improved academic performance using behaviour change programmes that are curative in nature.

\section{Conclusion}

The development of our country could also be measured by how far our children progress academically Goldman, (2005) related that "one reason most of our children are poor in academics is that as a society, we have not bothered to make sure that every child is reared well right from the home front". Nwadinobi, (2008) opined that the home teaching should complement the school programme. Thus to ensure positive academic performance in all our children, effective predictive parenting must be practiced in homes.

\section{Recommendations}

1. Counsellors are encouraged to initiate school-based-family counselling programmes in schools.

2. Counsellors' talks during PTA meetings and open days in school should centre on the need to adopt predictive parenting (techniques) in bring up children in homes: In other words, counsellors should intensify efforts to give adequate information to parents on the predictive parenting that leads to excellent academic performance in children.

3. Governments (Federal and state) non-governmental organizations and school authorities should give potential support to school counsellors that will enable them organize effective workshops, seminars, parent Fora from time to time on predictive parenting (technique) of child rearing in schools. They should provide adequate fund for counsellors to procure appropriate guidance materials such as TV's, video clips, posters and others to be used in driving home the real implication of predictive parenting (technique) to children's academic performance.

4. Professional counsellors should be posted to schools and be allowed to practice fully.

5. The training programme for professional counselling should be diversified to incorporate skills in school-based -family counselling for all counselling specialties' rather than being restricted to family counselling.

6. Predictive parenting should be integrated into some school subjects/courses like social studies, health education and civic education among others.

7. Parents should be encouraged to have discussion on predictive parenting (technique) with positive mind.

8. The Federal and state ministries of education, health and social welfare should mount more intervention programmes on predictive parenting technique of child up bringing in the country.

\section{References}

Adewunyi, T.D. (2010). Family background and students academic performances. (ASSON journal). Anagbogu M.A. (2009). Prevention of academic failure through counselling. ASSON proceedings 25-34.

Arikola A.O. (2010). Effects of school-based family counselling on academic achievement of children, Kaduna, Nigeria. ASSON VOL 1, 143-154.

Baumrind D. (1997). Parental disciplinary pattern and social competence in children. Youth and society (9) 280-276. 
Coleridge, S.T. (2009). "child training, its in your hands". Christen women mirrow. Magazine for building Godly children.

Cowon, L.A. (2003). New born and infants, retrieved http:Wikipedia.ary/with/parenting/1/20/2011.

Castaldi, B. (2007). Education facilities: Remolding and management. Boston Allyn and Bacon.

Daniel Goldman (2005). Home environment as determinants of children's learning. Journal of education (1), 26-34.

Harward, R. (2006). Home status, intelligence and attainment of higher education. Journal of education 74 (1) 100-123.

Hornby, A.S., Oxford Advanced Learners Dictionary of English.

I mon, M.E (2006). Child abuse and academic performance. Unpublished master's thesis Uncal. Nigeria.

Imon, M.E. and Asita, H.C. (2012). The state of education in Nigeria. West and Solomon publishing coy Onitsha, Nigeria.

Koo, L.N (). Beyond parental control and authoritarian parenting style. Journal of child rearing (4) 11111119 .

Maccoby, E.E. and Martins, J.A. (2006). Socializing in the context of the family. Social development $4^{\text {th }}$ ed. Pp 1-101. New York.

National Teachers Institute (2009). Psychology of education: transfer of learning PGDE/DLS, pp 180181., Kaduna.

National Policy on Education (2004). In FRN.

Ngeleoka, E.T. (2008). "WAEC not to blame for exam. Leakages". Daily times. J anuary.

Nwadinobi, V.N. (2010). Economic meltdown and parenting. Casson. Vol. (1), 56-64.

Nwaoba, C.N. (2011). Parenting Techniques in Africa for Psychology of Family and Widow Matters. Hudson-J ude Nigeria.

Nwazor, O.O.F. (2003). Effective Parent Child Communication: The key to successful nurture. Sunshine computer and press, Onitsha.

Nwankwo, O.L. (2005). Effects of study habit counselling on academic achievement of students. Casson, $\mathrm{Vol}(1), 2161$.

Nwideh Caesor (2001). "Ways to stop exam. leakages". Daily star, July 27 p. 11.

Obinajuruoha, R.N. (2004). Child rearing practices. The educational psychologists (6), 30-37.

Okeke, B.A. (2007). Child rearing practice: Principles of guidance and counselling. Snap Press, Enugu.

Okonkwo, G.N. (209). Parental training for academic success. Unpublished PGDE project, NTI Kaduna.

Olayinka, J.N.. (1998). Guidance and counselling, Lagos lantem books.

Popo, C.A. (1998). "Relationship between socio-economic status and academic achievement" Sapele. Unpublished M.Ed project, U.I., Nigeria.

Sears, Maccoby, E.E. and Levin (2003). Patterns of child rearing. New York. Evanston, Row Peterson.

Wilkerson, P. (2007). Manual of child psychology, New York: John Wiley and sons.

William, J.G. (2000). The family in New Delhi. Prentice hall of India. 